\title{
Risk assessment of radionuclide contamination spreading while flooding coal mined-out rocks
}

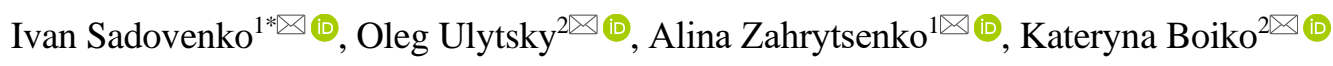 \\ ${ }^{1}$ Dnipro University of Technology, Dnipro, 49005, Ukraine \\ ${ }^{2}$ State Ecological Academy of Postgraduate Education and Management, Kyiv, 03035, Ukraine \\ *Corresponding author: e-mail zahrytsenko.a.m@nmu.one, tel.+380502550991
}

\begin{abstract}
Purpose. To investigate pathways and concentrations of the most dangerous radionuclides entering the surface and groundwater in terms of hydrodynamic situation re-establishment in the zone of radiation-hazardous mine field objects in the southern wing of the Central Donbas coal industrial region for environmental assessment.
\end{abstract}

Methods. Hydrodynamics and migration parameters characterizing the stage of mine workings' flooding - have been investigated. This phase is marked by the establishment of steady-state hydrodynamic regime with laminar groundwater filtration and radionuclide migration from the source of pollution to the river drainage. The parameters have been estimated on the basis of numerical modelling of geofiltration using available data from similar research and experimental studies. The resulting model has been calibrated by assessing the components of the water balance within the drainage area of the territory under research. Radionuclide migration pathways are defined by mathematical tools for mass-transfer calculation (MODPATH) using input parameters of the geofiltration model. To determine the concentration value of radionuclides entering the river drainage through the groundwater discharge, analytic calculations have been carried out. Facts and previous assumptions from different sources have been subjected to analytical comparison in order to outline the measures for control and technical settlement of possible threats and their ongoing assessment.

Findings. Predictive modelling of the initial phase of hydrodynamic regime stabilization during mine working flooding has been performed. Possible concentrations of $\mathrm{Sr}^{90}$ that are expected to enter the river drainage at the stage of groundwater level recovery to absolute marks $(+120 \ldots+145 \mathrm{~m})$ are calculated. It is found that the probability of $\mathrm{Cs}^{137}$ ions migration is very low, which can be explained by the specifics of migration mechanism. It has been demonstrated that radionuclide migration pathways differ in the form of distribution and groundwater flow directions at the final stage of mine flooding. It has been established that the developed continuously operating hydrochemical model of the region together with the application of actual monitoring data obtained from the underground and surface hydrosphere within the government-controlled area could be considered a practical tool of possible environmental threats control.

Originality. The research novelty is associated with the investigation of quantitative parameters of radionuclide migration within the abandoned coal mining areas on the basis of geofiltration modelling of current mine flooding conditions, when groundwater level reaches the critical mark, and the level stabilization process is accompanied by water resources recovery and water balance components transformation.

Practical implications. The proposed research technique enables to forecast environmental consequences of coal mines' flooding in Ukraine and to assess the hydrosphere pollution not only with radionuclides but also with other chemical elements; it also creates tools for control and management of negative environmental situations.

Keywords: coal, mine, flooding, geofiltration modelling, radioactive contamination

\section{Introduction}

The practice of coal mines closure in Germany, Great Britain, the USA, Poland and other countries is based on the follow-up use of water pumping and ensuring the appropriate technical status of the supporting (buffer) mines [1], [2], even when the mass shutdown of mines take place.

In Ukraine, in most cases, the mine closure means almost complete termination of any economic activity within the facili- ty, including termination of the drainage complex functioning, leading to the negative environmental impacts (surface flooding and subsidence, chemical pollution of river networks etc.).

A particularly critical situation has been forming within the area around the Central Donbas coal industrial region where 24 of the 27 previously operating mines are being closed.

It should be recognized that the flooding of mine workings is implemented almost without any reasonable measures 
as for its control. In terms of current situation - when flooding process of most mines within the Central Donbas coal industrial region is uncontrolled and complete flooding of mine workings instead of partial flooding takes place (under the optimization of the mine water management system), it is required to have visual representation of the process (by modelling) in order to predict negative environmental impacts and provide measures for threat minimization.

Flooding of the mine workings of Yunkom and Oleksandr-Zakhid mines as the high-risk objects is of particular concern. In 1979, Yunkom mine (south-eastern part of the Central Donbas coal industrial region) was the place for the Klivazh experiment carried out at the depth of $903 \mathrm{~m}$; the experiment aimed at creating additional fracturing of the rock mass to degas coal layers and reduce the probability of sudden coal and gas bursts. It is known that after the explosion, the Klivazh chamber could contain about $300 \mathrm{mEq}$ of radioactive contamination [3]. The dewatering complexes at the adjacent mines Chervonyi Zhovten and Poltavska stopped their operation in 2018 and 2014 respectively. According to the experts [4], flooding of the mine workings of Yunkom mine leaves open the possibility of explosive chamber destruction and further migration of maximally concentrated radioactively polluted water into the groundwater flow. Currently, there is no monitoring of radiation pollution of mine waters.

Thus, there is an urgent need to study and forecast the hydrodynamic situation in terms of flooding of both Yunkom and its adjacent mines including the evaluation of concentration of possible radionuclides entering the Bulavin River water in order to identify real measures to counteract the negative consequences of this process.

\subsection{Analysis of the recent studies and publications}

In Ukraine, the issues concerning the study and forecast of the hydrogeological conditions within the mine area were considered mainly as a part of technical solutions to substantiate the "wet conservation" measures (partial flooding) at certain mines. Those measures were based on the variant approaches providing water-pumping regime for "buffer" mines from among a group of mines being transferred to "wet conservation", and reflected mainly the technological aspects.

The two recent decades have demonstrated the formation of the national school of modelling of geofiltration and migration processes in the hydrogeological environment of mine fields.

The most comprehensive review of the hydrogeological modelling methods in terms of mine flooding conditions is represented in [5], [6]. The publication [7] covers environmental issues dealing with the assessment of the effects of mine working flooding - subsidence and water environment pollution.

There are notable controversial ideas on possible hydroand geomechanical damages to the chamber shell of the Klivazh object with further proposals as for geotechnological strengthening of mine workings and improvement of their sorption properties [4]. The detailed parametric analysis of the hydro- and geomechanics and migration processes within the affected zone of the object does not confirm that [8].

Thus, the problem concerning the object danger remains debatable and requires significant updating of scientific and practical approaches to its solution.

For a long time, the scientific principles of the geofiltration modelling within the mine fields have been covered in the studies by foreign scientists. The basis of geofiltration modelling is analyzed in the publications [9], [10]. The works by Polish [11] and German experts [12] deserve special attention as the example of best implementation of technical solutions as for coal mine closure, based on the modelling of flooding. However, the review of publications demonstrates that current scientific experience of forecasting a hydrodynamic situation within the flooded coal mine workings is applicable only in case of the controlled mine flooding. The scope of works devoted to the study of coal mine flooding conditions and its environmental consequences, that consider the conditions when groundwater level recovery has reached its critical absolute levels, is extremely limited.

\subsection{Objective and tasks of the research}

The objective is to identify the pathways and concentrations of the entry of the most dangerous radionuclides into the ground and surface waters under the hydrodynamics conditions within the radiation-hazardous objects of mine fields located in the southern wing of the Central Donbas coal industrial region to assess the environmental risks. To achieve the goal, the following tasks were solved:

- to specify hydrogeological parameters and to determine the water-balance components within the zones affected by the flooded mine workings;

- to carry out a forecast using numerical geofiltration modelling of the parameters of final flooding stage (absolute marks of the groundwater levels, directions of the groundwater flow, and ratio of the water-balance components);

- to define possible ways and concentrations of the entry of radiological contamination from the Klivazh explosive chamber (Yunkom mine) into the environment as a result of uncontrolled flooding of mines, and to design technically acceptable measures to control negative effects of this process and their prevention.

\section{Methods}

The plots, demonstrating the analysis of time-series tracking of flooding within the studied mines, were analyzed making it possible to identify the fact of formation of groundwater discharge into rivers. The available groundwater discharge indicates the transformation of water-balance components: renewal of drainage properties of rivers, being, in turn, a sign of achieving the equilibrium of hydrodynamic regime (Fig. 1). Quantitative indicators of the water balance correspond to those established in terms of the geofiltration regional model within the mine fields of the Central Donbas coal industrial region [8]. (a)

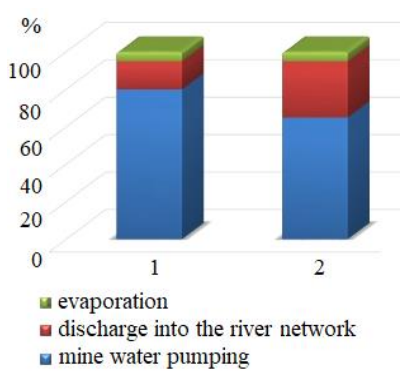

(b)

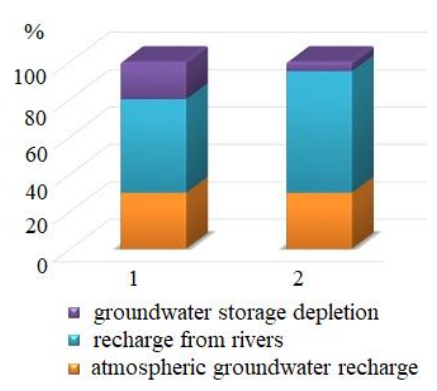

Figure 1. Ratio of the water balance components within the effect of mine fields: (a) outflow; (b) inflow; 1 -operational period; 2 -flooding period 
During the current stage of the formation of waterbalance ratio within the zones affected by flooded mines, the groundwater flow rate can be calculated for the boundaries of the studied area according to the following equation:

$Q_{g}=86.4 \cdot M_{g} \cdot F$

where:

$Q_{g}$ - the groundwater flow rate per area $F, \mathrm{~m}^{3} /$ day;

$M_{g}$ - the module of the groundwater flow discharge per $1 \mathrm{~km}^{2}, 1 / \mathrm{sec}$;

$F$ - the underground catchment area, $\mathrm{km}^{2}$.

In terms of the disturbed geological conditions of mine fields, module of the groundwater discharge $\left(M_{g}\right)$ and infiltration recharge $(W)$ may differ significantly from the known empirical and experimental values. Therefore, these parameters need to be clarified by simulating the numerical hydrodynamic calculations.

Distribution of the water-balance components as well as hydrogeological parameters within the hydrodynamic effect of mines being flooded was evaluated on the basis of a geofiltration model. Spatially, the model is the $70 \mathrm{~km}^{2}$ catchment area, comprising Chervonyi Zhovten, Yunkom, and Poltavska mine workings.

External outlines of the filtration area are represented by the second-kind boundary conditions with zero flow loss and the first-kind boundary conditions along the Bulavin River contour. The limit of the second-kind boundary conditions is along the watershed line of the catchment area of the Central Donbas coal industrial region, which coincides with the geological axis of the Donets anticlinorium, and along the sandstone outcrops of the water-bearing sets of series $\mathrm{C}_{2}{ }^{7}-\mathrm{C}_{2}{ }^{3}$. To simulate the flooding levels and to demonstrate the depression surfaces, modelling with the available internal boundaries of the flow within the mine fields was performed in the form of the boundary first-type conditions. Hence, hydraulic heads refer to the absolute drainage mark of the mine levels closest to the flooded surface. Taking into account current hydrodynamic conditions, in terms of which almost $95 \%$ of all mine workings were flooded, inverse and direct problem of geofiltration was solved. Since the process of water exchange was modelled at the depth of weathered coal deposit bedding $(\approx 120 \mathrm{~m})$, tectonic faults were not included into the model scheme. One-layer scheme of the model demonstrates the artificial aquifer medium within the weathered Middle Carboniferous formations. Values of hydrogeological parameters of Carboniferous aquifers, such as hydraulic conductivity $(K=0.38 \mathrm{~m} /$ day $)$, specific yields $(\mu=0.019)$, and specific storage $\left(\mu^{*}=0.00011\right)$, are taken from the hydrogeological studies of the rock mass of mine fields provided by geological institutions.

A period of 120 days corresponding to the duration of level increasing within Poltavska was specified as the reference modelling period. According to the results of preliminary analysis, that time period indicates the beginning of surface flow recharge recovery.

To simulate the surface groundwater level, the MODFLO software was used, based on the mathematical structure that incorporates solutions of the filtration differential equations by a finite-difference method, taking into account boundary conditions within the external and internal model contours.

The pollutants migration in groundwater flow is determined by both filtration area conditions and migratory prop- erties of the pollutants. The mechanisms of mass transfer of different radioactive components can differ. Thus, in case of $\mathrm{Sr}^{90}$, the mechanism of convective transferring in a solution prevails, i.e. with a lateral flow of artesian or nonartesian water. And for $\mathrm{Cs}^{137}$, which is easily absorbed by the solid phase of the rock, the diffusion process prevails. The upward filtration during the flooding of Yunkom mine workings, is obviously accompanied by the penetration of radioactive components into the radiogeochemically unsaturated rocks, even taking into consideration the probability of explosion chamber damage. The migratory properties of $\mathrm{Cs}^{137}$ ions will be determined mainly by its absorption within the rock masses. Therefore, it is expedient to estimate the concentrations of $\mathrm{Sr}^{90}$ ions (as the main radioactive pollutant) and the pathways of its migration towards the Bulavin River water, forced by the groundwater flow directions, in terms of the final stage of flooding.

Specialists of Kharkiv Institute of Physics and Technology (2004) established the initial concentrations of strontium-90 $(\approx 3700 \mathrm{~Bq} / \mathrm{l})$ that groundwater could contain in case of damage of the Klivazh explosive chamber. The ions migration during the upward filtration and further lateral filtration is accompanied by the processes of its destruction (nuclear fission). The concentration decrease of the parent substance $C_{1}$ can be described by the first-order differential equation [13]:

$$
\frac{\partial C_{1}}{\partial t}=-\lambda_{1} C_{1}
$$

where:

$\lambda_{1}-$ the fission parameter, days $^{-1}, \lambda_{1}=\ln 2 / T_{1} ;$

$T_{1}$ - the half-life period, days;

$t$ - the time of migration, days.

In terms of the known initial concentrations of the pollutant and known time interval, the differential expression of Equation (2) can be transformed into a parametric form (Cauchy solution):

$C_{1}=a \cdot \exp (-\lambda \cdot t)$

where:

$C_{1}$ - the value of the concentration decrease;

$a$ - the initial substance concentration;

$\lambda_{1}-$ the fission parameter, days ${ }^{-1}$;

$t$ - the time of migration, days.

The migration of $\mathrm{Sr}^{90}$ ions to the river network is forced by the horizontal filtration, which occurrence correlates with the beginning of the flooding regime stabilization or approaching the stationary filtration regime. The most probable directions of $\mathrm{Sr}^{90}$ ions migration are established by applying the mathematical mass transfer apparatus (MODPATH). The basis is the obtained and calibrated parameters of the geofiltration model and forecasted position of the groundwater levels.

When substantiating technically acceptable means of control of a possible negative scenario of radionuclide contamination, the results of previous studies, factual databases regarding the Central Donbas coal industrial region, and longterm experience of the article research co-author (O.A. Ulytsky) were analyzed.

\section{Results and discussion}

Flooding of mine workings within the reference period of observation, characterized by the groundwater discharge entry into the mine workings, was simulated basing on the 
proposed schematization of the research area. The reference period was detected by the beginning of groundwater discharge into the river network. It should be noted that a variant change of input parameters was applied to achieve more realistic reproduction of the flooding levels during the specified period within the mine fields. The model demonstrated its highest sensitivity to the value of infiltration recharge. Increase of the groundwater recharge value from 85 to $130 \mathrm{~mm} /$ year made it possible to reproduce the flooding levels being close to the observed ones. The increase in the groundwater recharge value is stipulated by significant fracturing of the weathering zone. The simulated flooding surface of levels distribution, based on the available geofiltration parameters, is represented in Figure 2.

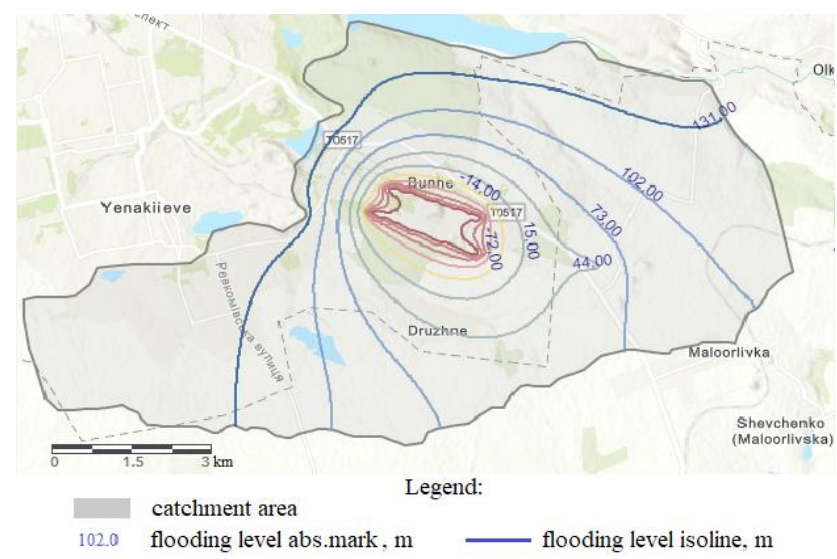

Figure 2. Scheme of the position of simulated flooding levels indirect model solution

Simulation errors are shown in Table 1.

Table 1. Errors of the identification of flooded mine levels within the reference period (120 days)

\begin{tabular}{lccc}
\hline \multirow{2}{*}{ Mine } & \multicolumn{2}{c}{$\begin{array}{c}\text { Absolute mark of flooding } \\
\text { level after a } 120 \text {-day period, } \mathrm{m}\end{array}$} & $\begin{array}{c}\text { Relative } \\
\text { error, \% }\end{array}$ \\
\cline { 2 - 4 } & Real & Simulated & \\
\hline Chervonyi Zhovten & -148.60 & -142.00 & 4.44 \\
Yunkom & -240.10 & -210.00 & 12.53 \\
Poltavska & 43.50 & 48.00 & 10.34 \\
\hline
\end{tabular}

A module of the groundwater flow discharge is calculated by Equation (1), taking into account the obtained value of groundwater flow rate; it equals $3.16 \mathrm{l} / \mathrm{sec}$ per $1 \mathrm{~km}^{2}$.

According to the simulation results, the stabilization time is 1740 days from the beginning of mine working flooding, and the representative absolute marks of groundwater levels under the flooding regime range as $+120 \ldots+145 \mathrm{~m}$. The water-balance components ratio for the prediction period is summarized in Table 2.

Table 2. Water-balance components ratio for the forecasted period of 1740 days from the beginning of mine working flooding

\begin{tabular}{lcc}
\hline \multicolumn{1}{c}{ Water-balance components } & Inflow & Outflow \\
\hline $\begin{array}{l}\text { Groundwater recharge } \\
\text { per area, } \mathrm{m}^{3} / \text { day }\end{array}$ & 37372 & -37372 \\
$\begin{array}{l}\text { Inflow from the first-order } \\
\text { boundary (the Bulavin }\end{array}$ & 2718 & - \\
$\begin{array}{l}\text { River), } \mathrm{m}^{3} / \text { day } \\
\begin{array}{l}\text { Groundwater discharge } \\
\text { into the river, } \mathrm{m}^{3} / \text { day }\end{array} \\
\text { Total, } \mathrm{m}^{3} / \text { day }\end{array}$ & - & -2368 \\
\hline
\end{tabular}

Figure 3 represents the predicted distribution of groundwater levels as the modelling result for the period of 1740 days from the beginning of mine working flooding.

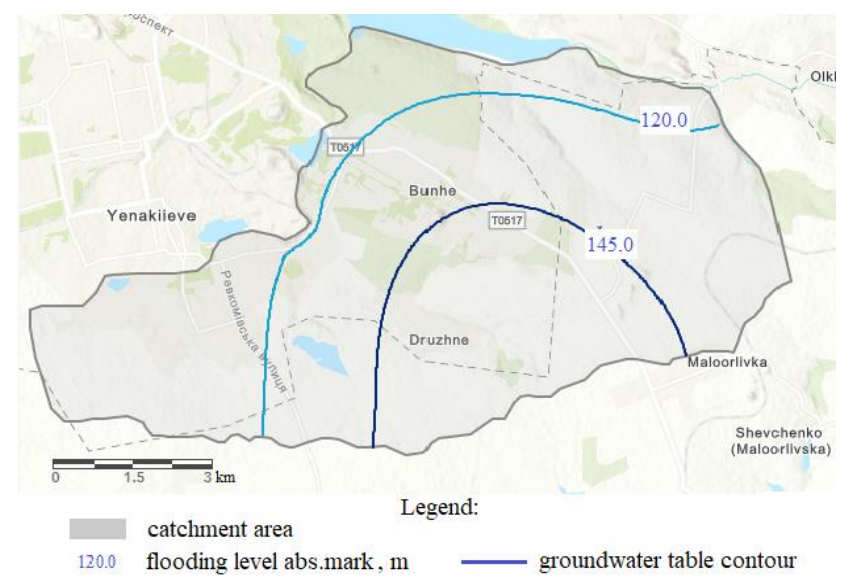

Figure 3. Predicted distribution of the groundwater levels (1740 days after the beginning of flooding)

While forecasting the radionuclides migration, it is taken into account that the half-life of $\mathrm{Sr}^{90}$ is 28.79 years. Accordingly, the fission parameter for $\mathrm{Sr}^{90}$ is 0.00006 .

The estimated time of concentration reduction, reflecting the period from the measurement of concentrations in 1991 to the predicted time of hydrodynamic stabilization, is 11967 days. In 1991, the Research Institute Promtekhnolohii carried out the testing of mine groundwater quality within the Klivazh chamber. The testing results showed the presence of $\mathrm{Sr}^{90}$ at the amount of $0.0296 \mathrm{~Bq} / 1$ (initial concentration, a) in mine waters. Then, the value of $\mathrm{Sr}^{90}$ concentration decrease, calculated according to Equation (3) at the moment of hydrodynamic stabilization around the mine field Yunkom and the adjacent shares of the catchment area, is $0.01443 \mathrm{~Bq} / \mathrm{l}$.

Therefore, possible concentration of $\mathrm{Sr}^{90}$, entering the surface hydrographic network at the time, that records the flooding levels reaching abs. marks $+120 \ldots+145 \mathrm{~m}$, would be expected to show $0.01517 \mathrm{~Bq} / \mathrm{l}$.

In comparison, the volume activity of radionuclides in the surface waters of Donbas region is estimated to be $0.0185 \mathrm{~Bq} / \mathrm{l}$ on average. Low concentration values of $\mathrm{Sr}^{90}$ are observed due to both sorption properties of rock mass and tightness of the explosive chamber. The $\mathrm{Sr}^{90}$ migration direction from the source of pollution (explosion chamber) to the river network is determined by the groundwater flow configuration and direction that would be stated as of 1740 day after the beginning of flooding. The most probable directions of $\mathrm{Sr}^{90}$-ions migration, defined by MODPATH mathematical tool application (mass transport option), are illustrated in Figure 4.

The predicted time point, reflecting the beginning of the steady-state hydrodynamic regime, is characterized by the error range as some mines workings (Chervonyi Zhovten and Yunkom) of the top levels have not been flooded so far. In addition, this may be due to the significant heterogeneity and anisotropy of the filtration properties of coal rocks that should be taken into account by further fragmentation of the model based on the data of monitoring observations. It is also known that if groundwater approaches the weathering and fracturing zones of the Middle Carboniferous rock masses (it is usually recorded at $150 \mathrm{~m}$ depth within the Central Donbas coal industrial region), one could observe the repeated activation of the earth's surface subsidence. 


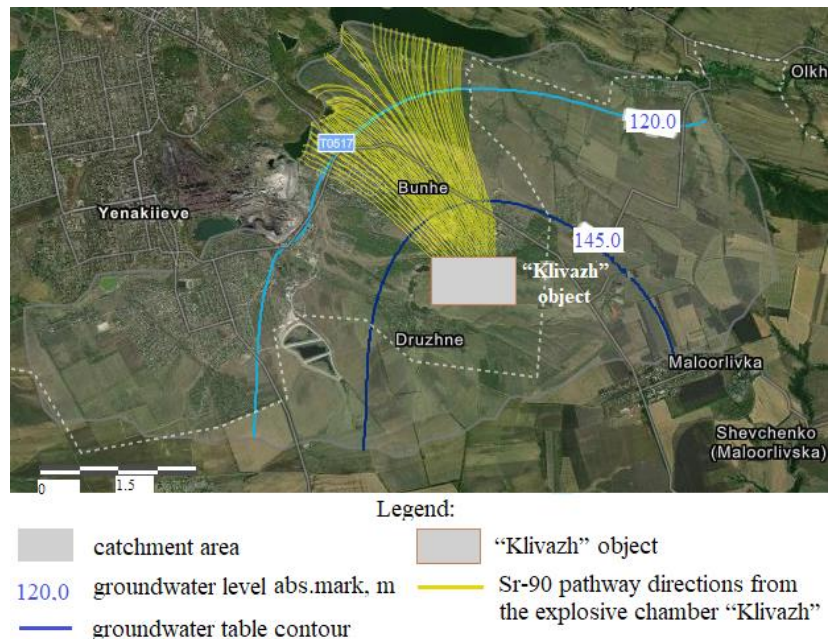

Figure 4. Directions of $\mathrm{Sr}^{90}$-ions migration under the steady-state hydrodynamic conditions (defined as a result of modelling and MODPATH package application)

Taking into consideration the significant size and complexity of rock displacement within the Central Donbas coal industrial region as well as a significant depth of man-made fracture spreading, the expected amplitude of vertical deformations of the earth's surface is more than 3-5 m. That does not exclude the possibility of formation of additional groundwater recharge zones, causing banked up water level. Further groundwater level increase can interrupt significantly the groundwater exchange process and cause flooding within the lowlands (the Bulavin River floodplain and ravine valleys).

The geological and hydrogeological conditions within the Central Donbas coal industrial region together with the significant negative environmental consequences of two hundred years of intensive coal mining as well as design and practice of mining operations with extremely low percent of costs (less than $10 \%$ of the prime coal cost) to provide the environmental stability in the region have resulted in a complex situation. In terms of that situation, it is impossible to attract sufficient financial and technical resources for transferring the object under the authors' study into the regime of guaranteed safety. A number of studies propose to implement extremely sophisticated technical measures, including highdepth (of about $1000 \mathrm{~m}$ ) well drilling with a set of geomechanical, hydrogeochemical, hydrodynamic, geophysical, and radiation tests to refine and adjust the forecasts. In addition, the proposed measures related to geomechanical strengthening of the "Klivazh" object and mine workings" filling with sorption materials within the pathways of migration flows, seem to be possible but extremely problematic.

Analysis of the factors and studies mentioned during the problem statement makes it possible to single out main grounds for more realistic scenario of transferring the analyzed object into the controlled regime, i.e.:

- the explosive chamber covered with a glasslike shell is in a flooded state, i.e. below the groundwater level. It was confirmed by well drilling into the chamber cavity in 1991;

- before the flooding of Yunkom mine workings, during the entire period the groundwater flow moved with hydrodynamic gradients and corresponding velocity, being much higher compared to the values typical for mine flooding regime, i.e. change in the intensity of radionuclides migration is corresponding;
- the local migration model performed for the above period did not provide any grounds to forecast the development of a dangerous scenario of radionuclide movement;

- the elementary consideration of the hydrostatics underground law together with strength properties of the rock mass within the Klivazh object shows that the effective stresses are expected to decrease down to $8 \mathrm{MPa}$ and almost coincide with the values of uniaxial compression strength of rocks, i.e. there are no conditions for geomechanical destruction of the radioactive zone.

Taking into consideration the abovementioned, the most realistic scenario may be as follows:

1. Scaling the developed model up with the emphasis and fragmentation of the most physically active components.

2. Defining the points of monitoring observations representing the state of the object within the controlled area (e.g. physicochemical parameters of surface waters).

3. Calibrating the model by epignostic solutions using the above described input data as well as its synthesis with the geomechanical fragment models.

4. Developing hydrodynamic modules according to the method [8], [14] in order to prevent (or to eliminate) the environmental danger, which is expected according to the current model forecast. Technical implementation of the module ensures the necessary redirection of the migration flows within the controlled areas; it also contains modular water-treatment blocks.

\section{Conclusions}

The study has helped determine the features of flooding regime of a typical group of mines within the outcropped Central Donbas coal industrial region: Chervonyi Zhovten Yunkom - Poltavska. These mines are hydraulically connected; though, they are characterized by different depths and volumes of mine workings. Basing on the graphoanalytical method of changes in flood levels over the reference time at Poltavska mine, periods of the formation of additional groundwater flow discharge have been identified.

The numerical geofiltration modelling has allowed evaluating the main values of hydrodynamic parameters and water balance components within the study area - the catchment area of the Bulavin River underworked by Chervonyi Zhovten, Yunkom, and Poltavska mine fields. The performed modelling and further model verification based on the water balance convergence, makes it possible to claim that groundwater level increase during the mine flooding is provided by groundwater flow-rate being about $821 \mathrm{~m}^{3} /$ hour and also by the groundwater recharge value of $130 \mathrm{~mm} /$ year.

The forecasted concentration of $\mathrm{Sr}^{90}$, that will enter the surface hydrographic network at the moment that will record the flooding levels at the abs. marks $+120 \ldots+145 \mathrm{~m}$, has been calculated. According to the preliminary calculations, it will be $0.01517 \mathrm{~Bq} / \mathrm{l}$, without the exceedance of permissible limits.

The possibility of $\mathrm{Cs}^{137}$-ions migration is very low since the mechanism of $\mathrm{Cs}^{137}$-ions migration means diffusion within a double diffusion layer (absorption by the solid soil phase of the soil). If the polluted waters reach the absolute marks of $+120 \ldots+145 \mathrm{~m}$, pathways of the $\mathrm{Sr}^{90}$ migration will be regulated by the shape of groundwater flow contours and the direction within the territories of mine working influence. 
A realistic scenario of transferring the analyzed object into the controlled regime and preventing possible hazards (in terms of current model forecast) has been substantiated.

The scenario is based on branching and scaling-up of the most active fragments of the filtration model and its synthesis with the geomechanical model. Current forecast data will be recorded within the controlled areas where it is possible to manage a dangerous situation with the help of mobile technological modules.

\section{Acknowledgements}

The results presented in the paper has been obtained without the financial support of any grant or a scientific project. The writing team expresses gratitude to the reviewers for the valuable recommendations that have been taken into account to significantly improve the quality of this paper.

\section{References}

[1] Westermann, S., Rudakov, D., Reker, B., \& Melchers, C. (2019). Ein neuer Blick auf Grubenwasseranstiegsprozesse - ausgewählte Beispiele aus dem deutschen Steinkohlenbergbau. Markscheidewesen, 126(1), 30-38.

[2] Malinowska, A.A., Witkowski, W.T., Guzy, A., \& Hejmanowski, R. (2020). Satellite-based monitoring and modeling of ground movements caused by water rebound. Remote Sensing, 12(11), 1786. https://doi.org/10.3390/rs12111786

[3] Dovhyi, S.O., Korzhnev, M.M., Kurylo, M.M., Malakhov, I.M., Trofymchuk, O.M., \& Chumachenko, S.M. (2012). Ekolohichni ryzyky, zbytky ta ratsionalni mezhi vykorystannia nadr $v$ Ukraini. Kyiv, Ukraina: Nika-Tsentr.

[4] Yakovlev, Ye.O., Yermakov, V.M., \& Ulytsky, O.A. (2019). Ekolohichni naslidky zatoplennia kamery atomnoho vybukhu shakhty
"Yunkom" (Tsentralnyi Donbas). Mineralni Resursy Ukrayiny, (1), 38-44. https://doi.org/10.31996/mru.2019.1.38-44

[5] Zahrytsenko, A., Podvigina, O., \& Dereviahina, N. (2018). Scientific and methodological foundations to develop numerical hydrodynamical models of mine fields in Donbas. E3S Web of Conferences, (60), 00034 https://doi.org/10.1051/e3sconf/20186000034

[6] Sadovenko, I., Zahrytsenko, A., Podvigina, O., Dereviahina, N., \& Brzeźniak, S. (2018) Methodical and applied aspects of hydrodynamic modeling of options of mining operation curtailment. Solid State Phenomena, (277), 36-43. https://doi.org/10.4028/www.scientific.net/SSP.277.36

[7] Ulytsky, O., Yermakov, V., Lunova, O., \& Buglak, O. (2018). Environmental risks and assessment of the hydrodynamic situation in the mines of Donetsk and Lugansk regions of Ukraine. Journal of Geology, Geography and Geoecology, 27(2), 368-376. https://doi.org/https://doi.org/10.15421/111861

[8] Sadovenko, I.A., Rudakov, D.V., \& Inkin, A.V. (2016). Geotekhnologiya osvoyeniya yemkostnykh $i$ gazotermal'nykh resursov Donbasa. Dnepr, Ukraina: NGU.

[9] Shuchita Garg, S.K. (2016). Singh modeling of arsenic transport in groundwater using MODFLOW: A case study. International Journal of Geomatics and Geosciences, 6(4), 56-81.

[10] Quiros, A.G., \& Fernández-Álvarez, J.P. (2019). Conceptualization and finite element groundwater flow modeling of a flooded underground mine reservoir in the Asturian Coal Basin, Spain. Journal of Hydrology, (578), 124036. https://doi.org/10.1016/i.jhydrol.2019.124036

[11] Szczepiński, J. (2019). The significance of groundwater flow modeling study for simulation of opencast mine dewatering, flooding, and the environmental impact. Water, 11(4), 848. https://doi.org/10.3390/w11040848

[12] Reker, B., Westermann, S., Goerke-Mallet, P., \& Melchers, C. (2020). Mine water rebound processes in Europe. SME Annual Conference and Expo.

[13] Rudakov, D.V. (2012). Matematychni metody v okhoroni pidzemnykh vod. Dnipropetrovsk, Ukraina: Natsionalnyi hirnychyi universytet.

[14] Sadovenko, I., Rudakov, D., \& Podvigina, O. (2010) Analysis of hydrogeodynamics in a mining region during exploitation till closure of coal mines. New Techniques and Technologies in Mining, 61-69. https://doi.org/10.1201/b11329-12

\section{Оцінка ризиків розповсюдження радіоактивного забруднення при затопленні гірського масиву вугільних шахт}

\section{I. Садовенко, О. Улицький, А. Загриценко, К. Бойко}

Мета. Встановити шляхи і концентрації надходження у підземну та поверхневу гідросферу найбільш небезпечних радіонуклідів в умовах відновлення гідродинамічної ситуації у зоні радіаційно небезпечних об’єктів шахтних полів південного крила Центрального району Донбасу для оцінки екологічного стану навколишнього середовища.

Методика. Для досягнення поставленої мети досліджені гідродинамічні та міграційні параметри етапу затоплення гірничих виробок шахт, що характеризується формуванням стаціонарного гідродинамічного режиму з ламінарною фільтрацію підземних вод і міграцією радіонуклідів від джерела забруднення до річкової мережі. Визначення параметрів здійснювалось на основі імітаційного чисельного моделювання геофільтрації та з використанням наявних даних аналогічних і експериментальних досліджень. Калібрування створеної моделі виконувалось шляхом оцінки складових водного балансу у межах водозбірної площі території дослідження. Напрямки міграції радіонуклідів встановлені шляхом застосування математичного апарату 3 розрахунку масопереносу (MODPATH) на основі використання вхідних параметрів геофільтраційної моделі. Визначення величини концентрації надходження радіонуклідів до річкової мережі із підземним стоком здійснювалось на основі аналітичного розрахунку. Для визначення засобів контролю й технічного врегулювання можливих загроз та їх поточного оцінювання проведено аналітичне співставлення фактів і попередніх пропозицій із різних джерел.

Результати. Виконане прогнозне моделювання початкової фази стабілізації гідродинамічного режиму в процесі затоплення шахт. Розраховані можливі концентрації $\mathrm{Sr}^{90}$, що надходитимуть у річкову мережу на етапі відновлення рівня підземних вод до абсолютних відміток $\left(+120 \ldots+145\right.$ м). Встановлено, що ймовірність міграції іонів $\mathrm{Cs}^{137}$ дуже низька, зважаючи на особливості механізму міграції. Показано, що шляхи міграції радіонуклідів визначаються формою розподілу та спрямованістю течій підземних вод на кінцевому етапі затоплення шахт. Визначено, що реальним інструментом контролю можливих екологічних загроз, є створення постійно діючої гідрохімічної моделі регіону з використанням фактичних даних моніторингу підземної та поверхневої гідросфери на підконтрольній частині території.

Наукова новизна. Досліджені кількісні параметри процесу міграції радіонуклідів у порушеному гірському масиві вугільних шахт на основі геофільтраційного моделювання сучасних умов затоплення гірничих виробок, коли рівень підземних вод досяг критичної позначки, а процес його стабілізації супроводжується відновленням водних ресурсів і трансформацією складових водного балансу.

Практична значимість. Запропонована методика дослідження може бути використана для прогнозу екологічних наслідків затоплення вугільних шахт України із можливістю оцінки забруднення гідросфери не тільки радіонуклідами, але й іншими хімічними елементами та створення засобів контролю та врегулювання негативних екологічних ситуацій.

Ключові слова: затоплення шахт, геофільтраційне моделювання, радіаційне забруднення 


\section{Оценка рисков распространения радиоактивного загрязнения при затоплении горного массива угольных шахт}

\section{И. Садовенко, О. Улицкий, А. Загриценко, Е. Бойко}

Цель. Установить пути и концентрации поступления в подземную и поверхностную гидросферу наиболее опасных радионуклидов в условиях восстановления гидродинамической ситуации в зоне радиоактивно опасных объектов шахтных полей южного крыла Центрального района Донбасса для оценки экологического состояния окружающей среды.

Методика. Для достижения поставленной цели исследованы гидродинамические и миграционные параметры горного массива на этапе затопления горных выработок шахт, который характеризуется формированием стационарного гидродинамического режима с ламинарной фильтрацией подземных вод и миграцией радионуклидов от источника загрязнения к речной сети. Определение параметров осуществлялось имитационным численным моделированием процесса геофильтрации с использованием фактических данных аналогичных и экспериментальных исследований. Калибровка модели выполнена путем оценки составляющих водного баланса в пределах водосборной площади территории исследования. Направление миграции радионуклидов установлено с использованием математического аппарата для расчета массопереноса (MODPATH) на основе входных параметров геофильтрационной модели. Величина концентрации радионуклидов, поступающих в речную сеть с подземным стоком, оценена аналитически. Для определения средств контроля, технического урегулирования возможных рисков и их текущего оценивания проведено аналитическое сопоставление фактов и предложений из разных источников.

Результаты. Выполнено прогнозное моделирование начальной фазы стабилизации гидродинамического режима в процессе затопления шахт. Рассчитаны возможные концентрации $\mathrm{Sr}^{90}$, поступающие в речную сеть на этапе восстановления уровня подземных вод до абсолютных отметок $\left(+120 \ldots+145\right.$ м). Установлено, что вероятность миграции ионов Сs ${ }^{137}$ достаточно низкая, учитывая особенности механизма миграции. Показано, что пути миграции радионуклидов определяются формой распределения и направленностью течений подземных вод на конечном этапе затопления шахт. Определено, что реальным инструментом контроля возможных экологических рисков, является создание постоянно действующей гидрохимической модели региона с использованием фактических данных мониторинга подземной и поверхностной гидросферы на подконтрольной территории.

Научная новизна. Исследованы количественные параметры процесса миграции радионуклидов в нарушенном горном массиве угольных шахт на основе геофильтрационного моделирования современных условий затопления горных выработок, когда уровень подземных вод достиг критической отметки, а процесс его стабилизации сопровождается восстановлением водных ресурсов и трансформацией составляющих водного баланса.

Практическая значимость. Предложенная методика исследований может быть использована для прогноза экологических последствий затопления угольных шахт Украины с возможностью оценки загрязнения гидросферы не только радионуклидами, но и другими химическими элементами, а также создания средств контроля и урегулирования негативных экологических ситуаций.

Ключевые слова: уголь, затопление, геофильтрачионное моделирование, радиационное загрязнение

\section{Article info}

Received: 22 April 2020

Accepted: 30 November 2020

Available online: 7 December 2020 